\title{
Alexandria, Egypt, before Alexander the Great: A multidisciplinary approach yields rich discoveries
}

Jean-Daniel Stanley*, Geoarchaeology Program, Rm. E-206, Paleobiology, Smithsonian Institution National Museum of Natural History (NMNH), Washington, D.C. 20013-7012, USA; Richard W. Carlson*, Carnegie Institution of Washington, Department of Terrestrial Magnetism, Washington, D.C. 20015, USA; Gus Van Beek*, Anthropology, Smithsonian Institution NMNH, Washington, D.C., 20013-7012, USA; Thomas F. Jorstad*, Geoarchaeology Program, Rm. E-206, Paleobiology, Smithsonian Institution NMNH, Washington, D.C. 20013-7012, USA; Elizabeth A. Landau*, Geological Sciences, San Diego State University, San Diego, California 92182-1020, USA

\section{ABSTRACT}

Historic records refer to Rhakotis as a settlement on Egypt's Mediterranean coast before Alexander the Great founded the famous Mediterranean port city of Alexandria in B.C. 332. Little is known of Rhakotis, however, because the site has yet to be clearly identified beneath the modern city. This problem motivated a geoarchaeological investigation of sediment cores from Alexandria's East Harbor, from which radiocarbon-dated sections of pre-Alexander age ( $>2300 \mathrm{yr}$ B.P.) have been obtained for study. These core sections comprise a number of critical components, five of which are emphasized here: ceramics, rock fragments derived from Middle and Upper Egypt, and sediment with markedly increased contents of lead, heavy minerals, and organic matter. A multidisciplinary approach, by which archaeological, stratigraphical, petrological, and geochemical methodologies are applied to study the five distinct core components, reaffirms that a sum can be greater than its parts. Together, the diverse markers in the dated core sections enable us to confirm human activity to at least seven centuries before B.C. 332 on the mainland coast, where Alexandria would later be established. Alexander's city, it now appears, rose from a preexisting town whose inhabitants had long before recognized the favorable harbor potential of this Egyptian coastal sector. The discoveries, providing direct evidence of the settlement's early (to ca. B.C. 1000) existence, are intended to prompt new exploratory efforts on land and offshore to further delineate that center's actual position and history.

\section{INTRODUCTION}

Coastal and marine geology are now well-established earth science subfields that developed from the turn of the twentieth century to the 1950s. Study of archaeological vestiges submerged in the marine realm, on the other hand, is a more recent scholarly pursuit, having evolved primarily after World War II. Integration of geological and archaeological sciences to investigate offshore sites has emerged in close association with the improvement of diving technology and equipment for offshore exploration. These include enhanced underwater drilling, photography, and television, along with refinement of applicable high-resolution seismic methodologies and surveys by research submarine and remote operated vehicle. Coastal geoarchaeology reached a subdiscipline threshold $\sim 25$ years ago, at the time of publication of the multi-authored volume on Quaternary coastlines and marine archaeology edited by Masters and Flemming (1983). Since then, the number of studies that emphasize integration of varied geological and archaeological approaches in the marine realm has progressively risen. Of special note is the increased use of a classic geological methodology, sediment coring, to help resolve archaeological problems at sites that presently lie beneath the waves. This subbottom technology has been applied with successful results in most world oceans, especially in the Mediterranean (Morhange et al., 2005; Marriner and Morhange, 2007; Stanley, 2007).

The present investigation integrates archaeological, geologi$\mathrm{cal}$, and geochemical data obtained from sediment cores that provide evidence of early human activity in the Alexandria region of Egypt. The focus is on identifying new information dated to well before the arrival of Alexander the Great, who founded this major Mediterranean port city in B.C. 332 (Fig. 1).

\section{BRIEF BACKGROUND}

Historians generally agree that Rhakotis, or Râ-Kedet, was a settlement established before the fourth century B.C. in the area subsequently developed as Alexandria. Rhakotis has been vaguely alluded to as a modest fishing village of little significance, a more substantial walled center, or possibly a fortified settlement (Fraser, 1972; Empereur, 1998; Baines, 2003; McKenzie, 2003; Ashton, 2004). The modern city of Alexandria, with nearly four million inhabitants and an extensive cover of municipal and industrial construction, has almost entirely buried the remains of earlier habitation (Empereur, 1998). Although a city area south of the Heptastadion (Fig. 2) is called Rhacotis (Rowe, 1954), no archaeological excavation to date has revealed the presence of an early pre-Alexandrian site.

A record of early nautical activity near Pharos Island, positioned $\sim 1 \mathrm{~km}$ seaward of the Alexandria mainland (Fig. 2), was initially passed down as oral history (from ca. B.C. 1200-1100) and then centuries later (B.C. 800-750) was recorded in Homer's epic Odyssey: "Now in the surging sea an island lies, - Pharos they call it, - By it there lies a bay with a good anchorage, from which they send the trim ships off to sea and get them drinking water." After Homer, historians and geographers intermittently refer to this Egyptian sector in their texts, such as Herodotus' The History (fifth century B.C.) and Strabo's Geographia (near the turn of the first century A.D.). Subsequently, scholars surmise that Minoan, Philistine, Phoenician, ancient Greek, and other early mariners sailing the eastern Mediterranean sought protection in the lee of Pharos Island long before Ptolemaic (B.C.

GSA Today: v. 17, no. 8, doi: 10.1130/GSAT01708A.1

*E-mails: stanleyd@si.edu; carlson@dtm.ciw.edu; vanbeekg@si.edu; jorstadt@si.edu; elandau@rohan.sdsu.edu 


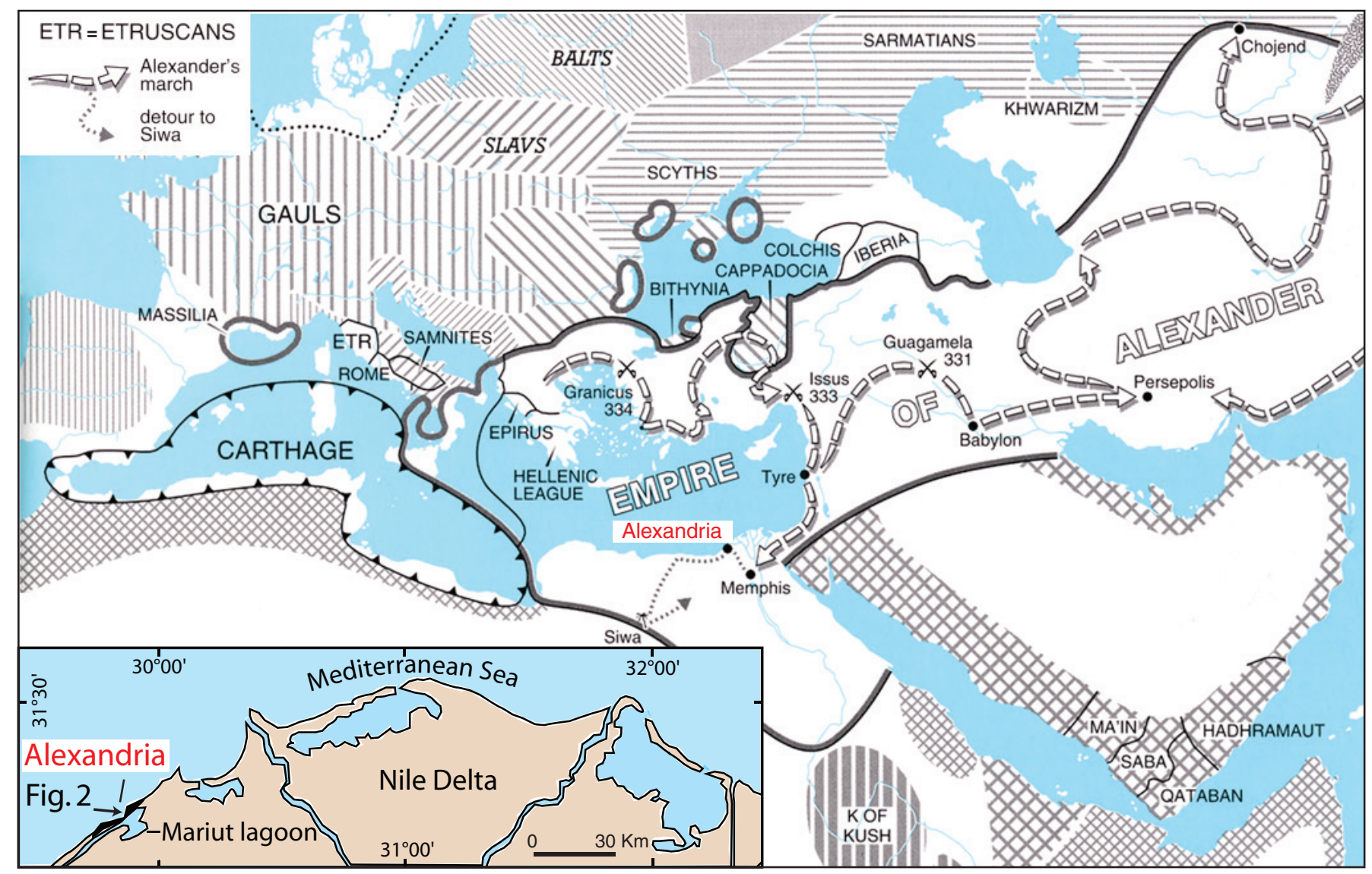

Figure 1. Map showing the geographic extent of Alexander the Great's empire and the Ptolemaic reign (post-B.C. 332) in the eastern Mediterranean (modified after McEvedy, 2002). Inset shows the Alexandria, Egypt, study area.

332-30) rule (Jondet, 1916; Weill, 1919). Additional evidence of pre-Alexander occupation in this region is provided by early archaeological sites in proximal sectors (Egypt Exploration Society, 2005), including those along the Mariut lagoon to the south (Rowe, 1954) and the Nile delta coast to the east of Alexandria (Stanley, 2005, 2007).

Recent preliminary findings record more direct evidence of settlement prior to the Ptolemies in, or proximal to, the modern city. These are based on assessments of cores collected on land adjacent to the East Harbor of Alexandria (Goiran et al., 2000; Véron et al., 2006) and in the East Harbor proper (Stanley and Landau, 2005). New findings summarized herein are obtained by a comprehensive and multidisciplinary study of dated cores recovered in the harbor.

\section{METHODS}

The present East Harbor basin covers an area of $\sim 2.5 \mathrm{~km}^{2}$ and is bound to the south by an arcuate coastline bordered by the city of Alexandria (Fig. 2). The region has been the focus of numerous investigations, including geography (Goddio et al., 1998), oceanography (Inman and Jenkins, 1984), geology and paleogeography (Warne and Stanley, 1993; Goiran et al., 2005), stratigraphy (Goiran et al., 2000), sedimentology (ElWakeel and El-Sayed, 1978; Wali et al., 1994), and geochemistry (Véron et al., 2006).

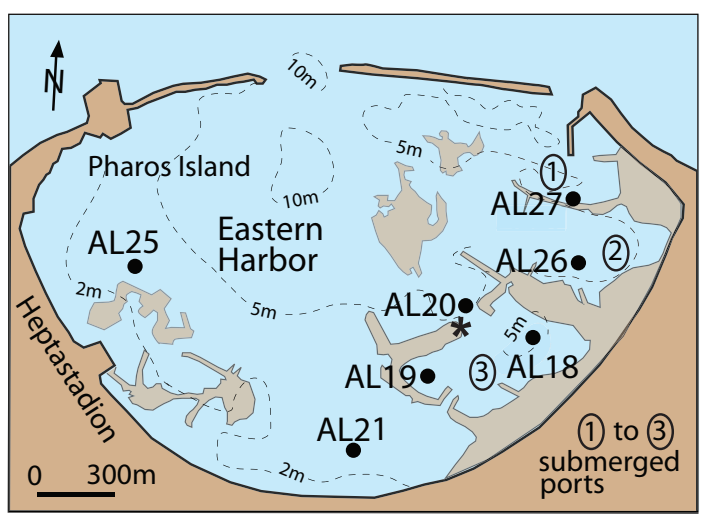

Figure 2. Configuration of the Eastern Harbor and locations of seven vibracore sites off Alexandria. Light brown features in the Eastern Harbor are shallow reefs and submerged port structures (after Goddio et al., 1998). Asterisk denotes eastern end of now-subsided Antirhodos Island, where late fifth and early fourth century B.C. wood was recovered.

New information to define this basin's early Holocene to present evolution is provided by seven vibracores (lengths $\sim 2.0-5.5 \mathrm{~m}$; Fig. 3) collected in the East Harbor (Stanley and Bernasconi, 2006). The 52 Accelerator Mass Spectrometry (AMS) dates obtained for core samples are given in uncalibrated ${ }^{14} \mathrm{C}$ 


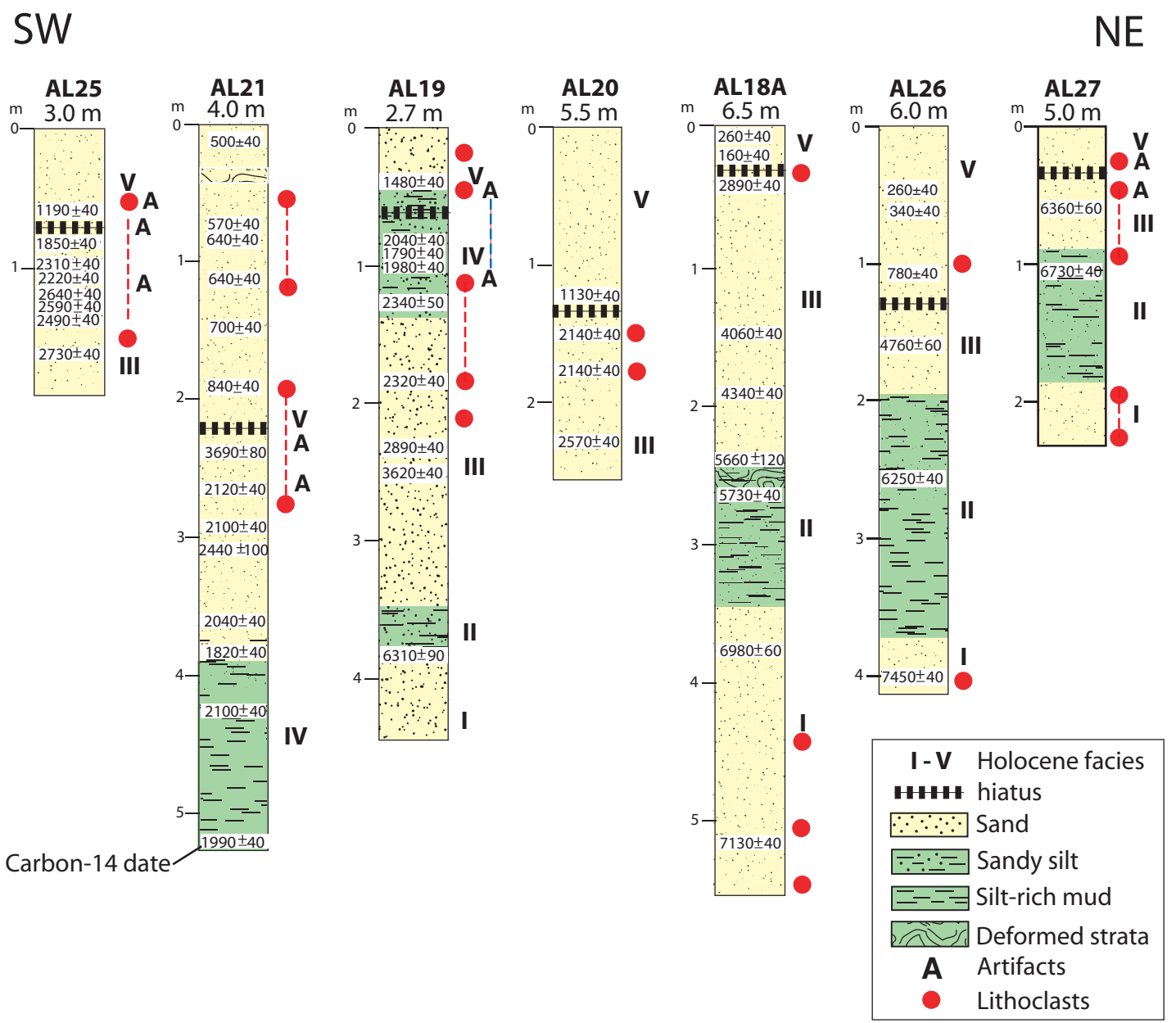

Figure 3. Stratigraphic logs of the seven vibracores collected in the East Harbor, showing five dominant lithofacies (I-V), conventional radiocarbon (uncalibrated) dates (in thousand yr B.P.), and positions of artifacts and lithoclasts. Modified after Stanley and Bernasconi (2006).

radiocarbon years (most shown in Fig. 3). Samples $(n=441)$ were taken throughout the sand-rich cores at $<15 \mathrm{~cm}$ intervals for petrologic study. Lithological logs of the cores and results of different analyses are given in Stanley and Bernasconi (2006).

Lead isotopic analyses were performed at the Carnegie Institution of Washington. After addition of a ${ }^{205} \mathrm{~Pb}$ spike, $\sim 20-50$ $\mathrm{mg}$ of coarse core material was dissolved, and the $\mathrm{Pb}$ was separated and analyzed using procedures described in Carlson et al. (2006). Some samples, labeled with an "L" in Table 1, were first subjected to an acetic acid leach. In most cases, $>50 \%$ of the sample was dissolved in the acetic acid. After leaching, the residue was dissolved as described above, while the leach was first dried and then redissolved in $\mathrm{HBr}$ in preparation for $\mathrm{Pb}$ separation. All measured $\mathrm{Pb}$ isotopic compositions are corrected for mass fractionation based on these average standard values compared to the isotopic composition of NBS 981 reported by Todt et al. (1996).

\section{OBSERVATIONS}

\section{Core Content in Greek to Recent Time}

Stratigraphic analysis of dated borings identifies five mostly carbonate lithofacies (coded I to V) from base to top of East
Harbor cores (Figs. 3 and 4A): Lower Sand (I) and Lower Mud (II) units of early to mid-Holocene age (>7500 to ca. $5600 \mathrm{yr}$ B.P.); Middle Sand (III) facies of mid- to late Holocene age (ca. 5600-2300 yr B.P.); and Upper Mud (IV) and Upper Sand (V) of late Holocene age since Ptolemaic rule $(<2300$ yr B.P.). Core AL19 comprises all five stratigraphic facies, with a basal section older than $6310 \pm 90$ radiocarbon yr B.P., and thus serves as a representative, or type, boring to define changes through time denoted by diagnostic archaeological, geological, and geochemical criteria.

Upper Sand (V) and Upper Mud (IV) sections in this and other East Harbor cores comprise the most abundant and diverse suites of archaeological material. These upper two units contain potsherds, pebble-size rock clasts, and high concentrations of heavy minerals (Fig. 4D), lead (Fig. 5A), organic matter, quartz, and crystalline and aggregate limestone, when compared to the three older facies (I-III). Rapid municipal development during the reign of the Ptolemies and Romans gave rise to marked anthropogenic signals in the two upper lithofacies. For example, very high lead concentrations (>100 ppm) occur in post-Alexander sediment in core AL19 (Fig. 5A); this is also recorded in core sections of this age collected on land in Alexandria proper (Goiran et al., 2000; Véron et al., 2006). The 
findings denote heavy lead use by Greeks and Romans during Alexandria's swift expansion.

Accelerated construction along the mainland shore and in the East Harbor proper (Fig. 2) during this time (IV-V) is amply recorded (Empereur, 1998; Goddio et al., 1998; Hesse, 1998), including the building of the Heptastadion, the large freshwater aqueduct-causeway system between the city and Pharos Island (Hesse, 1998; Goiran et al., 2000, 2005). Increased organic matter content in upper core facies IV and $\mathrm{V}$ includes fibers of Phragmites sp. and algae. Such materials were derived from the city's sewage runoff and from Alexandria Canal discharge into the harbor (Stanley and Bernasconi, 2006).

\section{Key Markers in Pre-Greek Time}

Until now, the record of human activity in Alexandria prior to the Ptolemies has been sorely limited. Underwater diver excavation at the eastern end of now-submerged Antirhodos Island (marked by an asterisk in Fig. 2) recovered posts of elm (Ulmus sp., a non-local wood) radiocarbon-dated (calibrated calendar years) at B.C. $410 \pm 40$ and planks of pine (Pinus sp.) at B.C. $395 \pm 40$ (Goddio et al., 1998).

Materials found in cores recovered in the East Harbor, however, provide more ample evidence of older pre-fourth century B.C. (>2400 yr B.P.) human activity, especially in sediment forming the upper part of the Middle Sand (III) unit in East Harbor cores (Fig. 4A). Foremost are potsherds of early age that were recovered in this part of unit III in core AL25, in the western East Harbor (Fig. 3). Ceramic fragments include coarse and poorly fired material, mostly cooking vessels, although some thinner ceramics from bowls and small jars are also observed. The pottery is wheel-made and appears to be of local production rather than imported. Archaeological analysis of ceramic fragments, including ones preserved with slip (Fig. 4B, 1-2) and others that are rimmed (Fig. 4B, 3-4), show they are most closely comparable to typical southeastern Mediterranean ware made in the ninth to seventh centuries B.C. (plates 81-83 in Tufnell, 1953; National Museum of Natural History collections). These potsherds and lithic fragments prevail in sediment radiocarbon dated to well before 2330 yr B.P. (calibrated dates of B.C. 940 to B.C. 420).

Most cores include carbonate pebbles derived from exposures proximal to the East Harbor that originated in the lower (older) sections of cores AL18A, AL26, and AL27. Core AL19 also contains pebble-sized rock fragments (diorite, gabbro, quartzite, marble, and dense fossiliferous limestone) in the upper half of facies III at a depth of $2.3 \mathrm{~m}$ from core top (Fig. 4C). These lithoclasts, with diameters of $1-5 \mathrm{~cm}$, are of non-local (allochthonous) derivation and were obtained from distant quarries, mostly in Middle and Upper Egypt. This upper facies III section, positioned $>50 \mathrm{~cm}$ beneath the base of the Upper Mud (IV) unit, is radiocarbon dated as older than ca. 2320 yr B.P. but younger than $2890 \pm 40$ yr B.P. (Fig. 4A). Rock reached Alexandria's East Harbor either by vessel or overland transport for use in building structures; in the case of core site AL19, located $\sim 500 \mathrm{~m}$ from the present coastline (Fig. 2), this material was likely brought to localities near the southern East Harbor margin. Some clasts may also have been derived from materials recycled from statuary or other artifacts of Egyptian
TABLE 1. Pb CONCENTRATION AND ISOTOPIC COMPOSITION OF ALEXANDRIA CORE SEDIMENTS AND ARTIFACTS

\begin{tabular}{|c|c|c|c|c|c|c|}
\hline $\begin{array}{l}\text { Sample } \\
\text { no. }\end{array}$ & $\begin{array}{c}\text { Depth } \\
\text { (cm) }\end{array}$ & Sample & $\begin{array}{l}{[\mathrm{Pb}]} \\
\mathrm{ppm}\end{array}$ & $204 / 206$ & $207 / 206$ & $208 / 206$ \\
\hline TJ1 & 56 & Clayey silt & 171 & 0.05401 & 0.84601 & 2.08725 \\
\hline $\mathrm{TJ} 2$ & 96 & Clayey silt & 286 & 0.05409 & 0.84785 & 2.09116 \\
\hline TJ9 & 120 & Shelly silt & 102 & 0.05367 & 0.84034 & 2.07878 \\
\hline TJ24 & 123 & Carbonate sand & 84 & 0.05395 & 0.84481 & 2.08589 \\
\hline TJ25 & 126 & Carbonate sand & 78 & 0.05362 & 0.84187 & 2.08423 \\
\hline TJ16 & 129.5 & Silty carbonate sand & 49 & 0.05363 & 0.84263 & 2.08632 \\
\hline TJ17 & 139 & Silty carbonate sand & 48 & 0.05370 & 0.84271 & 2.08528 \\
\hline TJ18 & 149.5 & Silty carbonate sand & 65 & 0.05350 & 0.84089 & 2.08428 \\
\hline TJ3 & 159 & Dark clay & 68 & 0.05341 & 0.83923 & 2.08245 \\
\hline TJ10 & 183 & Silt w/shell frag. & 83 & 0.05330 & 0.83602 & 2.07573 \\
\hline TJ10L & 183 & Silt w/shell frag. & 74 & 0.05330 & 0.83621 & 2.07632 \\
\hline TJ11 & 204.5 & Fine silt & 56 & 0.05318 & 0.83394 & 2.06831 \\
\hline TJ11L & 204.5 & Fine silt & 51 & 0.05319 & 0.83388 & 2.06732 \\
\hline TJ12 & 226 & Silt w/shell \& rock frags. & 52 & 0.05314 & 0.83391 & 2.06727 \\
\hline TJ12L & 226 & Silt w/shell \& rock frags. & 43 & 0.05315 & 0.83338 & 2.06554 \\
\hline TJ26 & 230 & Silty sand & 16.7 & 0.05318 & 0.83566 & 2.07105 \\
\hline TJ27 & 235 & Silty carbonate sand & 15.9 & 0.05339 & 0.83691 & 2.07127 \\
\hline TJ28 & 240 & Silty carbonate sand & 13.6 & 0.05335 & 0.83762 & 2.07550 \\
\hline TJ13 & 243 & Silt w/shell frags. & 37 & 0.05367 & 0.84127 & 2.08179 \\
\hline TJ13L & 243 & Silt w/shell frags. & 22 & 0.05387 & 0.84342 & 2.08225 \\
\hline TJ19 & 245 & Clayey sand & 8.2 & 0.05376 & 0.84249 & 2.07925 \\
\hline TJ20 & 247 & Clayey sand & 12.1 & 0.05374 & 0.84323 & 2.08363 \\
\hline TJ21 & 249 & Clayey sand & 10.4 & 0.05365 & 0.84089 & 2.07847 \\
\hline TJ4 & 251 & Clayey silt & 1.99 & 0.05397 & 0.84348 & 2.07967 \\
\hline TJ29 & 273 & Silty carbonate sand & 0.66 & 0.05321 & 0.83064 & 2.05908 \\
\hline TJ30 & 326 & Sandy silt carbonate & 0.74 & 0.05312 & 0.83082 & 2.05704 \\
\hline TJ5 & 349 & Silty sand & 4.36 & 0.05323 & 0.83250 & 2.06064 \\
\hline TJ31 & 405 & Silty carbonate sand & 1.12 & 0.05314 & 0.82924 & 2.05593 \\
\hline \multicolumn{7}{|c|}{ Archaeological samples } \\
\hline TJ6 & Met & al artifact, Core AL25 & 6.65 & 0.05425 & 0.84835 & 2.08671 \\
\hline TJ14 & Cera & amic glaze, Core AL25 & 49 & 0.05391 & 0.84389 & 2.08343 \\
\hline TJ15 & Cera & amic no glaze, Core AL25 & 17.9 & 0.05341 & 0.83703 & 2.07152 \\
\hline TJ22 & Cera & amic, Core AL25 & 17.1 & 0.05349 & 0.83855 & 2.07631 \\
\hline TJ23 & Cera & amic, Core AL25 & 128 & 0.05356 & 0.84093 & 2.08351 \\
\hline TJ32 & $\mathrm{Pb} \mathrm{c}$ & $\mathrm{crab}$ & $30.4 *$ & 0.05325 & 0.83646 & 2.07953 \\
\hline TJ33 & Woc & oden coffin lid & 83 & 0.05341 & 0.83182 & 2.05998 \\
\hline TJ34 & Clay & y cartouche & 206 & 0.05389 & 0.84465 & 2.08873 \\
\hline TJ35 & Terr & a cotta figurine & 18.6 & 0.05366 & 0.83853 & 2.07095 \\
\hline TJ36 & Mur & mmy case & 190 & 0.05767 & 0.87327 & 2.10021 \\
\hline TJ37 & Clay & y vase & $17.0 *$ & 0.05029 & 0.79379 & 2.00047 \\
\hline
\end{tabular}

Note: Artifacts TJ32-TJ37 from the Smithsonian Institution's Egyptian and Nile delta materials collection. $\mathrm{Pb}$ concentrations determined by isotopic dilution using a

${ }^{205} \mathrm{~Pb}$ spike. Uncertainties on $\mathrm{Pb}$ concentration: $<1 \%$. Isotopic compositions have uncertainties of ${ }^{204 / 206} \mathrm{~Pb}=0.06 \%,{ }^{207 / 206} \mathrm{~Pb}=0.10 \%$, and ${ }^{208} \mathrm{~Pb} /{ }^{206} \mathrm{~Pb}=0.12 \%$.

Sample numbers ending in "L" are acetic acid leaches; residues of leaching are denoted by the same sample number without the "L" ending. ${ }^{*} \mathrm{wt} \%$.

dynastic origin. Polished, flat, well- to very well-rounded clasts are typical of rock worn on a beach or in a shallow aqueous setting subject to strong swash action (Stanley, 2005).

Similarly, in the mid- to upper section of the Middle Sand (III) unit there is a marked increase in proportions of heavy minerals (to 1\%; Fig. 4D) and organic matter content (to $1.5 \%$ by weight; Stanley and Landau, 2007). As with potsherds and rock clasts, the increased content of heavy minerals and organic matter found in carbonate-rich facies dated prior to Ptolemaic rule are associated with increased human activity. Construction activity involved use of noncarbonate rock material and sediment transported to the area, while organic matter 

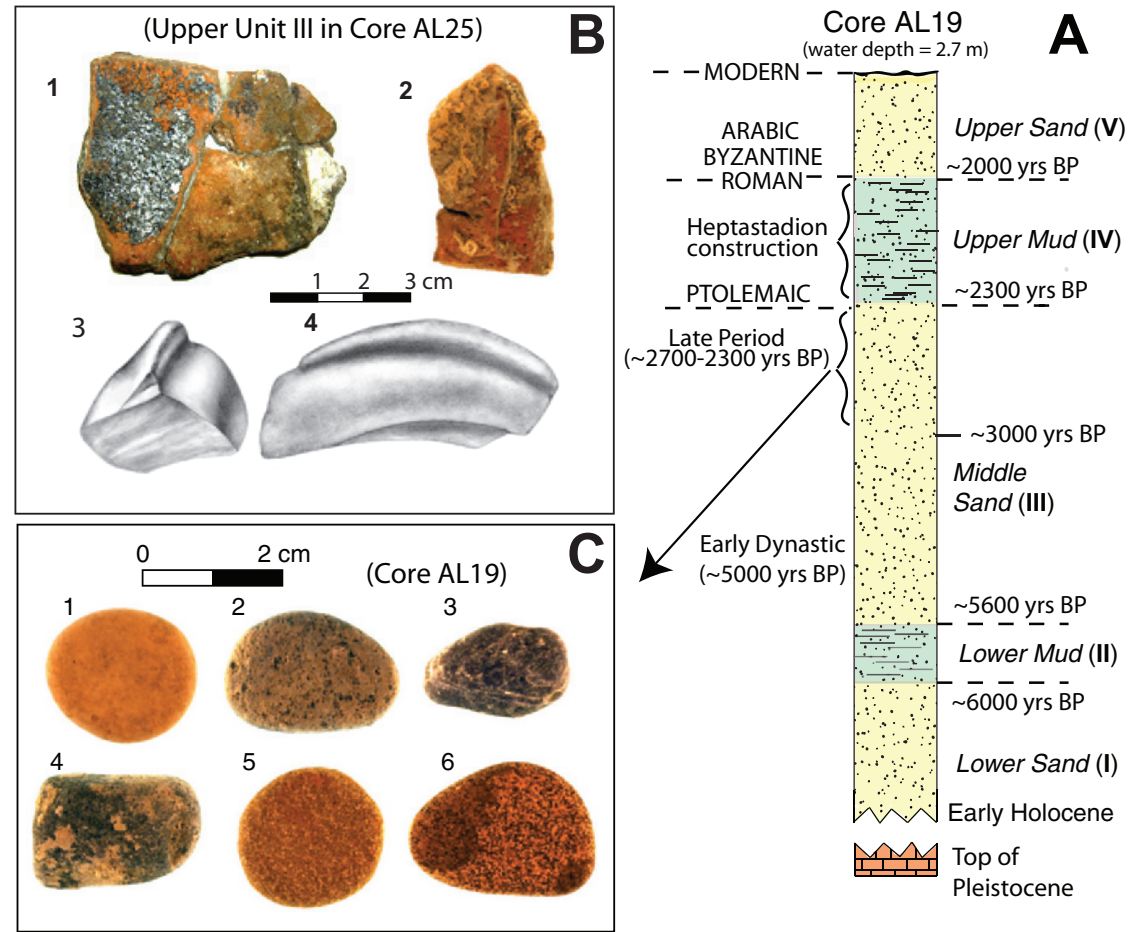

Sample

depth $(\mathrm{cm}) \quad$ Core AL19 Heavy Mineral (\%)

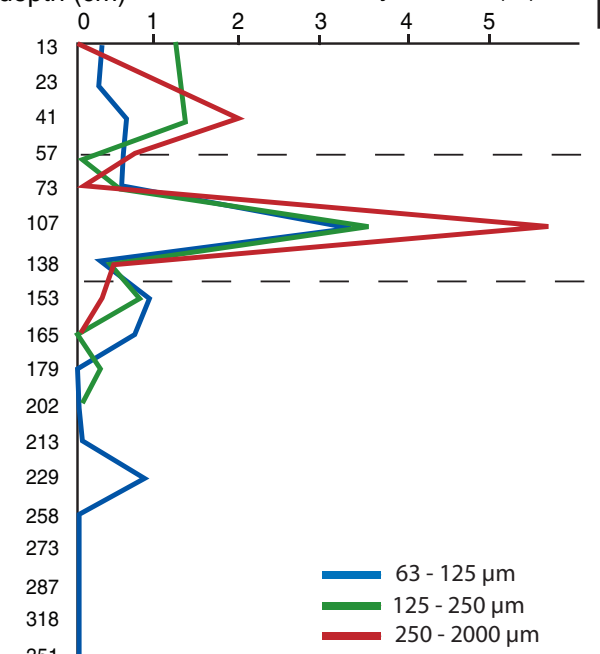

351
368
378
400
413
427

Figure 4. (A) Lithologic log of type core AL19 showing five (I-V) dated stratigraphic units. (B) Sherds of representative ware locally produced and dated from ninth and eighth centuries B.C.: slip $(1,2)$ and rimmed (3, 4). (C) Examples of pebbles of diverse lithologies derived from Middle and Upper Egypt, dated from ca. 3000-2300 yr B.P., recovered in upper part of unit III in core AL19. 1, 2-fossiliferous limestone; 3, 4-quartzite; 5-diorite; 6-gabbro. (D) Relative percentage of heavy mineral content in very fine, fine, and medium sand-size fractions, with marked increase in upper part of unit III before 2300 yr B.P.; major peak occurs in unit IV during Alexandria's development by Greeks and Romans.
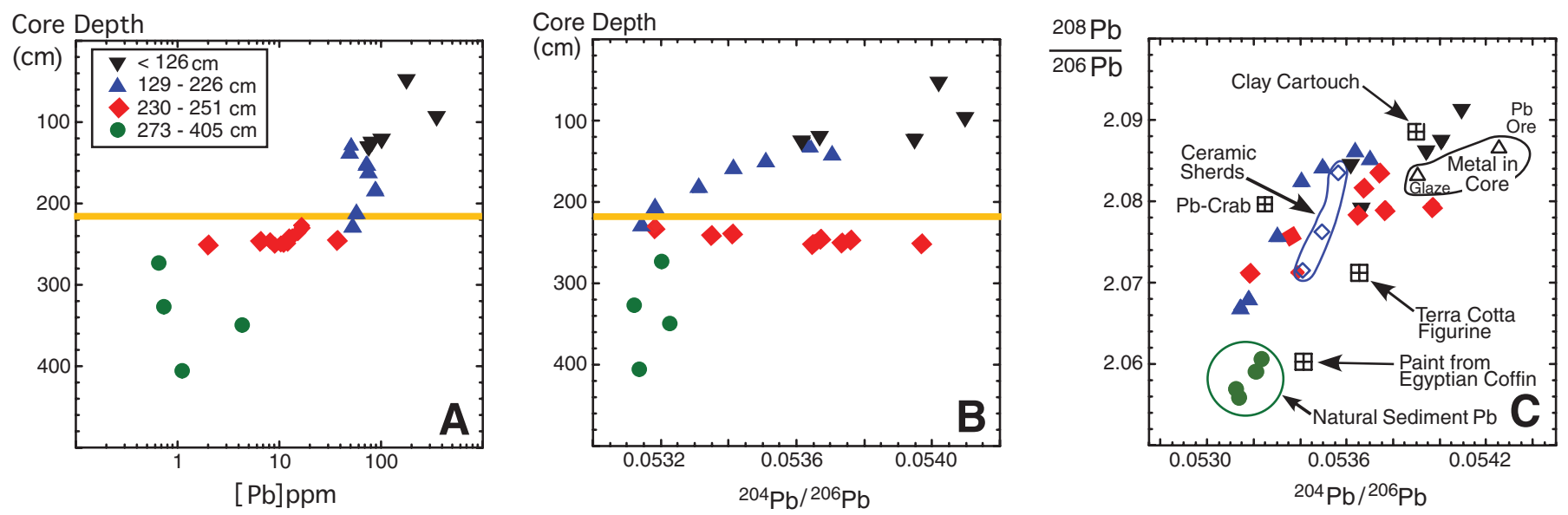

Figure 5. (A) Lead concentration, in ppm on a log-scale. (B) Isotopic ratio $\left.{ }^{204} \mathrm{~Pb} / 206 \mathrm{~Pb}\right)$ versus depth in AL19; horizontal yellow lines denote ca. 2300 yr B.P. Alexander timeline. Major changes in both concentration and isotopic ratio occur between ca. 2900 and 2300 yr B.P. Samples color-coded by depth in core. (C) Isotopic ratios ${ }^{208} \mathrm{~Pb} / 206 \mathrm{~Pb}$ versus $\left.{ }^{204} \mathrm{~Pb} /{ }^{206} \mathrm{~Pb}\right)$ of sediment in core AL19 and artifactual material, including ceramic and metal from core AL25 and pre-Alexandria artifacts in the Smithsonian Institution's Lower Egypt collections (see Table 1). Ceramic fragments in the core are identified by open blue diamonds. Artifactual materials are shown by cross-hatched boxes. Potential representatives of anthropogenically concentrated $\mathrm{Pb}$ are provided by samples from cores that include a metal fragment and glaze from ceramic potsherds in core AL25 (open triangles). 
was discharged into the East Harbor by increasing volumes of municipal waste water.

\section{Geochemical Markers in Pre-Greek Time}

In addition to the four archaeological and petrologic parameters, lead concentration and isotopic composition in core AL19 (see Table 1) present a formidable additional line of evidence of human activity prior to B.C. 332. Lead concentrations are consistently below $10 \mathrm{ppm}$ at depths $>251 \mathrm{~cm}$ from core top (e.g., sections in the lower part of unit III that are older than ca. 4000 yr B.P.; Fig. 5A). From 251-230 cm (deposition in pre-Alexander time), $\mathrm{Pb}$ concentration gradually increases, reaching 50-80 ppm through depths of $123 \mathrm{~cm}$ (Ptolemaic time). Above $120 \mathrm{~cm}, \mathrm{~Pb}$ concentrations increase to $>100 \mathrm{ppm}$, marking substantial $\mathrm{Pb}$ input into the East Harbor following accelerated growth of Alexandria by Greeks and Romans, as also documented by Véron et al. (2006).

In all samples below $251 \mathrm{~cm}$, both ${ }^{204} \mathrm{~Pb} /{ }^{206} \mathrm{~Pb}$ and ${ }^{208} \mathrm{~Pb} /{ }^{206} \mathrm{~Pb}$ ratios are slightly lower than values typical of average continental crust (e.g., ${ }^{204} \mathrm{~Pb} /{ }^{206} \mathrm{~Pb}=0.0535$ and ${ }^{208} \mathrm{~Pb} /{ }^{206} \mathrm{~Pb}=2.0658$; Stacey and Kramers, 1975). These values are indicative of the isotopic composition of natural $\mathrm{Pb}$ deposited in sediment prior to human influence. Throughout the post-Alexander portion of the core (above $226 \mathrm{~cm}$ depth), $\mathrm{Pb}$ concentrations are very high (>43 ppm) and show continually increasing ${ }^{204} \mathrm{~Pb} /{ }^{206} \mathrm{~Pb}$ and ${ }^{208} \mathrm{~Pb} /{ }^{206} \mathrm{~Pb}$ ratios upsection in the core (Fig. $5 \mathrm{~B}$ ), consistent with increasing input of pollutant $\mathrm{Pb}$ from ore sources (Véron et al., 2006). Potential examples of this material include the metal fragment and ceramic glaze recovered from core AL25 (Fig. 5C).

Of special note, however, is that $\mathrm{Pb}$ concentration and isotopic composition do not correlate at the onset of anthropogenic $\mathrm{Pb}$ contamination in the interval between $251 \mathrm{~cm}$ and $183 \mathrm{~cm}$ from core top. Within the $251-235 \mathrm{~cm}$ interval, ${ }^{204} \mathrm{~Pb} /{ }^{206} \mathrm{~Pb}$ ratios increase to values similar to those seen in the shallowest portions of the core, yet both $\mathrm{Pb}$ concentrations and ${ }^{208} \mathrm{~Pb} /{ }^{206} \mathrm{~Pb}$ (Fig. 5C) remain below those characterizing the shallow portions of the core. Between $\sim 230$ and $183 \mathrm{~cm}$ from core top, $\mathrm{Pb}$ concentrations increase dramatically, yet ${ }^{204} \mathrm{~Pb} /{ }^{206} \mathrm{~Pb}$ ratios drop to values similar to those of the natural sediment $\mathrm{Pb}$, but with significantly higher ${ }^{208} \mathrm{~Pb} /{ }^{206} \mathrm{~Pb}$. This may indicate an initial burst of anthropogenic $\mathrm{Pb}$ contamination into the East Harbor involving a source of $\mathrm{Pb}$ different from the ore-leads characteristic of the post-Alexander era.

The core component between 251 and $183 \mathrm{~cm}$ depth, characterized by high ${ }^{208} \mathrm{~Pb} /{ }^{206} \mathrm{~Pb}(\sim 2.07$ to $\sim 2.084)$ and moderate ${ }^{204} \mathrm{~Pb} /{ }^{206} \mathrm{~Pb}(\sim 0.0532$ to $\sim 0.0538)$ is similar in isotopic composition to ceramic potsherds from core AL25 that date to preAlexandrian times (Figs. 4B and 5C). These ceramic fragments have only moderate $\mathrm{Pb}$ concentrations (17-128 ppm), at least compared to weight percent concentrations in the analyzed pigments and metals (Table 1), and thus explain the relatively modest $\mathrm{Pb}$ concentration increase but marked $\mathrm{Pb}$ isotopic variation between 251 and $230 \mathrm{~cm}$ depth in the core. These data suggest that the first significant anthropogenic $\mathrm{Pb}$ contribution to East Harbor sediments did not derive from Greek and Roman metalworking, but instead reflect deposition of clay used perhaps for both building construction and manufacturing of ceramic vessels. The area surrounding the East Harbor is dominantly carbonate (Stanley and Bernasconi, 2006), so the clay signature is not likely to be locally (in situ) sourced. Only well into the post-Alexandria period did $\mathrm{Pb}$ pollution in the East Harbor shift to isotopic compositions expected for anthropogenically concentrated $\mathrm{Pb}$; for example, as associated with metallurgy, paints, and pigments.

\section{CONCLUSIONS}

The more approaches utilized in an archaeological investigation, the greater the possibility of attaining robust new findings. Results from the application of diverse geological methodologies in this study provide consistent data on five distinct and diverse components in radiocarbon-dated East Harbor cores: ceramics, allochthonous rock fragments, lead concentration, heavy minerals, and organic matter, which all increase substantially in the same upper part of the Middle Sand (III) unit dated to ca. $3000 \mathrm{yr}$ ago. Stratigraphically, this depositional phase clearly corresponds to one that began well before the arrival of Alexander in B.C. 332.

Together, the five archaeological, petrological, and geochemical markers provide compelling evidence of human activity dating to as much as seven centuries before the development of Alexandria by the Ptolemies. In particular, the ceramic sherds, lead isotopes, and associated data collected from harbor sediment cores indicate that a coastal population flourished in this area during Egypt's Intermediate (ca. B.C. 1000) and Late Dynastic (pre-Ptolemaic) periods.

In summary, evidence from East Harbor cores shows that Alexandria did not grow from a barren desert, but was built atop an active town that had for centuries exploited the safe harbor setting along this Egyptian coast. Beyond providing a preliminary insight into the early settlement's history, it is expected that the investigation findings will provide impetus for further geoarchaeological exploratory efforts in this historically rich region.

\section{ACKNOWLEDGMENTS}

We appreciate valuable technical assistance from and discussions with K.M. Carnes, J.-P. Goiran, A. Logan, M. Parish, M. Richardson, E. Smith, S. Sorenson, F. Tera, and M. Waigan. Constructive reviews that helped improve the article were made by N.A. Ellis, C. Finkl, S.T. Johnston, S.H. Parcak, and S. Soter. Funding was generously provided by F. Goddio and the Institut Européen d'Archéologie Sous-Marine in Paris, France; the Hilti Foundation; the Smithsonian Institution's National Museum of Natural History and Marine Science Network; and the Carnegie Institution of Washington.

\section{REFERENCES CITED}

Ashton, S.-A., 2004, Ptolemaic Alexandria and the Egyptian tradition, in Hirst, A. and Silk, M., eds., Alexandria, real and imagined: London, Ashgate, p. 15-40.

Baines, J., 2003, Appendix: Possible implications of the Egyptian word for Alexandria: Journal of Roman Archaeology, v. 16, p. 61-63.

Carlson, R.W., Czmanske, G., Fedorenko, V., and Ilupin, I., 2006, A comparison of Siberian meimechites and kimberlites: Implications for the source of high-Mg alkalic magmas and flood basalts: Geochemistry, Geophysics, Geosystems, v. 7, no. 11, doi: 10.1029/2006GC001342.

Egypt Exploration Society, 2005, EES Delta Survey (reference collection of archaeological sites in the Egyptian Nile Delta): http://www.ees.ac.uk/deltasurvey/dsintro.html (accessed 25 May 2007).

El-Wakeel, S.K., and El-Sayed, M.Kh., 1978, The texture, mineralogy and chemistry of bottom sediments and beach sands from the Alexandria region, Egypt: Marine Geology, v. 27, p. 137-160, doi: 10.1016/0025-3227(78)90077-4.

Empereur, J.-Y., 1998, Alexandrie Redécouverte: Paris, Stock, 253 p.

Fraser, P.M., 1972, Ptolemaic Alexandria (3 vols.): London, Oxford University Press, $2136 \mathrm{p}$.

Goddio, F., Bernand, A., Bernand, E., Darwish, I., Kiss, Z., and Yoyotte, J., 1998, Alexandria, the Submerged Royal Quarters: London, Periplus, $274 \mathrm{p}$. 
Goiran, J.-P., Morhange, C., Bourcier, M., Carbonel, P., and Morigi, C., 2000 Evolution des rivages d'Alexandrie à l'Holocène récent, marge occidentale du delta du Nil, Egypte: Méditerranée, v. 94, no. 1.2, p. 83-90.

Goiran, J.-P., Marriner, N., Morhange, C., Abd El-Maguib, M., Espic, K., Bourcier M., and Carbonel, P., 2005, Evolution géomorphologique de la façade maritime d'Alexandrie (Egypte) au cours des six derniers millénaires: Méditerranée, v. 104 , no. 1.2 , p. $61-64$.

Herodotus, The History, Translated by D. Greene, 1987: Chicago, The University of Chicago Press, 699 p.

Hesse, A., 1998, Arguments pour une nouvelle hypothèse de localization de I'Heptastade d'Alexandrie: Alexandrina, v. 1, p. 1-33.

Homer, The Odyssey, Translated by G.H. Palmer, 2003: New York, Barnes \& Noble Classics, 339 p.

Inman, D.L., and Jenkins, S.A., 1984, The Nile littoral cell and man's impact on the coastal zone of the southeastern Mediterranean: Scripps Institution of Oceanography: Reference Series, v. 31, p. 1-43.

Jondet, M.G., 1916, Les Ports Submergés de l'Ancienne île de Pharos: Cairo, L'Institut Egyptien, $101 \mathrm{p}$

Marriner, N., and Morhange, C., 2007, Geoscience of ancient Mediterranean harbours: Earth-Science Reviews, v. 80, p. 137-194, doi: 10.1016/j.earscirev.2006. 10.003 .

Masters, P.M., and Flemming, N.C., eds., 1983, Quaternary Coastlines and Marine Archaeology: London, Academic Press, 641 p.

McEvedy, C., 2002, The New Penguin Atlas of Ancient History: London, Penguin Books, 128 p.

McKenzie, J., 2003, Glimpsing Alexandria from archaeological evidence: Journal of Roman Archaeology, v. 16, p. 35-63.

Morhange, C., Goiran, J.-P., and Marriner, N., eds., 2005, Coastal geoarchaeology of the Mediterranean: Méditerranée, v. 104, no. 1.2, p. 1-131.

Rowe, A., 1954, A contribution to the archaeology of the Western Desert: Bulletin of the John Rylands Library, v. 36, p. 128-145.

Stacey, J.S and Kramers, J.D, 1975, Approximation of terrestrial lead isotope evolution by a two-stage model: Earth and Planetary Science Letters, v. 26, p. $207-$ 221, doi: 10.1016/0012-821X(75)90088-6.

Stanley, J.-D., 2005, Submergence and burial of ancient coastal sites on the subsiding Nile delta margin, Egypt: Méditerranée, v. 104, p. 65-73.
Stanley, J.-D., ed., 2007, Geoarchaeology, Underwater Excavations in the Canopic Region of Egypt: Oxford, Oxford Centre for Maritime Archaeology, $128 \mathrm{p}$

Stanley, J.-D., and Bernasconi, M.P., 2006, Holocene depositional patterns and evolution in Alexandria's Eastern Harbor, Egypt: Journal of Coastal Research, v. 22, p. 283-297, doi: 10.2112/04-0348.1.

Stanley, J.-D., and Landau, E.A., 2005, Early human activity (pre-332 BC) in Alexandria, Egypt: New findings in Eastern Harbor cores: Eos (Transactions, American Geophysical Union) Fall Meeting Supplement, v. 86, no. 52, p. F1252.

Stanley, J.-D., and Landau, E.A., 2007, New petrological findings in Eastern Harbour cores, Alexandria, in Cole, J., ed., City and Harbour, the archaeology of ancient Alexandria: Oxford, Oxford University Press (in press)

Strabo, The Geography, Translated by H.L. Jones, 1917-1932: Cambridge, Harvard University Press, 8 volumes.

Todt, W., Cliff, R.A., Hanser, A., and Hofmann, A.W., 1996, Evaluation of a ${ }^{202} \mathrm{~Pb}$ ${ }^{205} \mathrm{~Pb}$ double spike for high-precision lead isotope analysis, in Hart, S.R., and Basu, A., eds., Earth Processes: Reading the Isotope Code: Washington D.C., American Geophysical Union, p. 429-437.

Tufnell, O., 1953, Lachish III: The Iron Age, text and plates: London, Oxford University Press, $437 \mathrm{p}$.

Véron, A., Goiran, J.P., Morhange, C, Marriner, N, and Empereur, J.Y, 2006 Pollutant lead reveals the pre-Hellenistic occupation and ancient growth of Alexandria, Egypt: Geophysical Research Letters, v. 33, L06409, doi: 10.1029/2006GL025824.

Wali, A.W.A., Brookfield, M.E., and Schreiber, B.C., 1994, The depositional and diagenetic evolution of the coastal ridges of northwestern Egypt: Sedimentary Geology, v. 90, p. 113-136, doi: 10.1016/0037-0738(94)90020-5.

Warne, A.G., and Stanley, J-D. 1993, Late Quaternary evolution of the northwestern Nile delta and adjacent coast in the Alexandria region, Egypt: Journal of Coastal Research, v. 9, p. 26-64

Weill, R., 1919, Les ports antéhelléniques de la côte d'Alexandrie et l'empire crétois: Bulletin de l'Institut Français d'Archéologie Orientale, v. 16, p. 1-37.

Manuscript received 2 February 2007; accepted 8 May 2007.

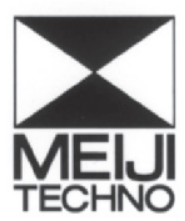

TII

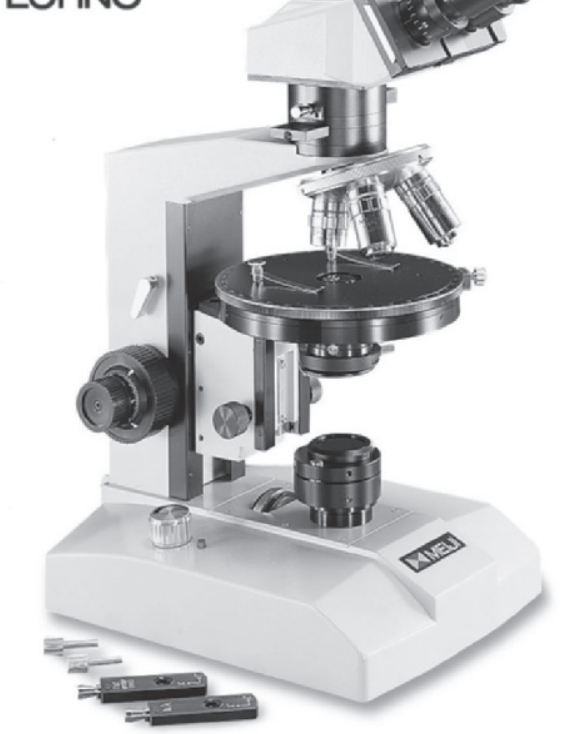

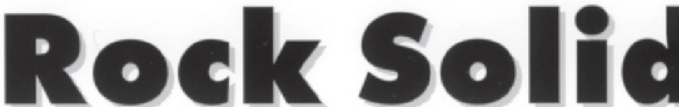

\section{Meiji ML Series Polarizing Microscopes}

Solid as a rock and crystal clear is what you will find when you look into these Polarizing Microscopes.

Each ML 9000 Series Microscope is equipped with swing-in, swing-out polarizer, analyzer and Bertrand lens for extra-bright, extra large interface figures. Every package includes DIN standard compensators (Mica 1/4 wave plate and first order red plate), strain free optics and a $360^{\circ}$ graduated rotatable stage. You have a choice of 3 bodies - monocular, binocular or trinocular and a full range of accessories to create the ideal instrument for your specific needs and Meiji stands behind every instrument with its "Limited Lifetime Warranty."

For more information on these economically priced Microscopes, please call, FAX, write us or log on to our website today.

\section{MEIJI TECHNO AMERICA} 3010 Olcott Street, Santa Clara, CA 95054-3027

Toll Free Telephone: 800.832 .0060 or visit our website at www.meijitechno.com 